University of Wollongong

Research Online

Faculty of Business - Papers (Archive)

Faculty of Business and Law

2019

Earnings Quality and Corporate Social Disclosure: The Moderating Role of State and Foreign Ownership in Vietnamese Listed Firms

Trang Cam Hoang

Ton Duc Thang University, tch855@uowmail.edu.au

Indra Abeysekera

Charles Darwin University, indraa@uow.edu.au

Shiguang Ma

University of Wollongong, shiguang@uow.edu.au

Follow this and additional works at: https://ro.uow.edu.au/buspapers

Part of the Business Commons

Research Online is the open access institutional repository for the University of Wollongong. For further information contact the UOW Library: research-pubs@uow.edu.au 


\title{
Earnings Quality and Corporate Social Disclosure: The Moderating Role of State and Foreign Ownership in Vietnamese Listed Firms
}

\author{
Abstract \\ By investigating the effect of earnings quality (EQ) on corporate social disclosure (CSD) in the context of \\ Vietnam, this study tests whether firms uphold managerial opportunism based on the agency theory or \\ social responsibility based on stakeholder theory. It also tests the moderating effect of state and foreign \\ ownership on the relationship between EQ and CSD. This study finds that the long-term perspective \\ argument dominates in the relationship between EQ and CSD, indicating that EQ is positively and \\ significantly associated with CSD. The study also finds that the increasing proportion of shares held by \\ the government in firms weakens the relationship between EQ and CSD. \\ Disciplines \\ Business

\section{Publication Details} \\ Hoang, T. C., Abeysekera, I. \& Ma, S. (2019). Earnings Quality and Corporate Social Disclosure: The \\ Moderating Role of State and Foreign Ownership in Vietnamese Listed Firms. Emerging Markets Finance \\ and Trade, 55 (2), 272-288.
}




\section{Earnings Quality and Corporate Social Disclosure:}

\section{The Moderating Role of State and Foreign Ownership in}

\section{Vietnamese Listed Firms}

\section{Trang Cam Hoang ${ }^{1}$, Indra Abeysekera ${ }^{* 2}$, and Shiguang $\mathrm{Ma}^{3}$}

${ }^{1}$ Faculty of Finance and Banking, Ton Duc Thang University, Ho Chi Minh City, Vietnam.

Email: hoangcamtrang@,tdtu.edu.vn

${ }^{2}$ Business School, Charles Darwin University, Darwin NT 0800, Australia.

Email: indra.abeysekera@cdu.edu.au

${ }^{3}$ School of Accounting, Economics and Finance, University of Wollongong, Wollongong NSW 2522, Australia. Email: shiguang@uow.edu.au

\footnotetext{
* Corresponding author: Professor Indra Abeysekera, Business School, Charles Darwin University, Darwin NT 0800, Australia; Tel: +61; email: indra.abeysekera@cdu.edu.au
} 


\begin{abstract}
By investigating the effect of earnings quality on corporate social disclosure (CSD) in the context of Vietnam, this study tests whether firms uphold managerial opportunism based on the agency theory or social responsibility based on stakeholder theory. It also tests the moderating effect of state and foreign ownership on the relationship between earnings quality and CSD. This study finds that the long-term perspective argument dominates in the relationship between earnings quality and CSD, indicating that earnings quality is positively and significantly associated with CSD. The study also finds that the increasing proportion of shares held by the government in firms weakens the relationship between earnings quality and CSD.
\end{abstract}

Keywords: earnings quality, corporate social disclosure, agency theory, stakeholder theory 


\section{Introduction}

The debate about managers behaviour whether self-centered or altruistic has re-surfaced with the broadened disclosure that comprise financial and non-financial with non-financial taking a large volume in annual reports and company websites. The debate has taken a center stage with non-financial disclosure such as corporate social disclosure (CSD) because they are voluntary and often not subjected to a formal audit. For instance, Prior, Surroca, and Tribo (2008) reported that multinational firms across 26 countries used CSD to diverge attention from earnings management. Choi, Lee, and Park (2013) subsequently found in the context of Korea that ownership structure can influence managerial motivation to engage in CSD. The accelerated economic growth in Vietnam, not only makes a loud appeal for foreign capital but has taken into a period of transitional flux from state ownership to private ownership of enterprises, with a mix of partially state-owned and partially foreign-owned enterprises. The economic welfare of the Vietnamese society depends not only on the public funding but also private activities and taking responsibility for the society (Vorobyeva and Phuong, 2017). These findings from the literature bring forth examining the relationship between CSD and earnings quality not only to contribute to the public policy in Vietnam but also to contribute to a broader understanding as a few studies have examined the influence of earnings quality on CSD Yip, Staden, and Cahan 2011, Chih, Shen, and Kang 2008, Kim, Park, and Wier 2012.

The managerial motivation behind CSD has come under much debate but the managerial motivation in the context of earnings quality on CSD has received little attention. Certain managerial motivations are identifiable through actions taken by them, certain other managerial motivations are implicit in actions and become noticeable through outcomes. In this study, we take the position that the firm ownership (to the extent of state ownership, or foreign ownership) as an implicit motivation for managers to take a perspective on CSD. 
Managers can take a short-term opportunistic perspective or a long-term efficiency perspective on CSD. When firms report earnings that are sustainable, predictable, and less manipulated by accruals, it is indicative that firms' earnings are reported responsibly and predictably. It is likely that firms can take a long-term efficiency perspective on CSD. However, in an emerging nation such as Vietnam, there is also a possibility that managers behave opportunistically to benefit from the expansive economic growth.

Our empirical results and contributions resulting from those findings are as follows. First, the standardised aggregate earnings quality is positively correlated with CSD when all firms are considered. The finding contributes to the understanding that managers can take an efficient perspective in non-financial disclosure, along with the established notion that managers take an opportunistic view on financial disclosure. The divided managerial perspective between financial and non-financial disclosure can inform owners and policymakers about divergent frameworks and accountabilities required for the two strands of disclosure. Second, this relationship becomes weaker with the state having increasing ownership in firms, which suggests that when the earnings quality becomes low in a stateowned company, the state-owned company is likely to decrease the stakeholder-relevant CSD. The finding informs the statutory policymakers to closely monitor the nature and the magnitude of state influence on managers efficiency perspective and may consider including CSD and their activities as part of audit to uphold public policy performance matrix on economy, efficiency, and effectiveness. Third, our evidence shows that foreign ownership has no moderating effect on the relationship between earnings quality and CSD. The finding contributes to the public policy framework to hold foreign ownership in Vietnam become responsible not only to contribute through taxes but also through socially beneficial activities to Vietnam and requiring such disclosure in annual reports. Fourth, the three-dimensional CSD index developed in this study contributes to a methodological improvement in 
measuring stakeholder-relevant CSD, making findings and facilitate stakeholder-relevant policy revisions.

\section{Related literature and hypotheses}

Agency theory is based on the premise that there is an inherent conflict between the interests of a firm's owners (shareholders) and its management (Fama and Jensen 1983). Therefore, firms may use different methods, such as compensation plans or voluntary disclosures, to reduce conflicting interests between managers and shareholders. Accounting information is made by agents to communicate financial position, performance, and change in financial position to principals. Any information asymmetry between the mangers and shareholders can lead to the moral hazard problem. Agency theory on corporate social responsibility/CSD, argues that managers can opportunistically use corporate resources to pursue goals that enhance their own utility in ways that are unlikely to provide significant returns to shareholders. For example, Vanhamme and Grobben (2009) find that firms using corporate social responsibility in times of crisis can uphold reputation only when they have a history of corporate social responsibility disclosure. Accordingly, Friedman (1970) argues that companies that take part in corporate social responsibility practices only want to benefit from the reputation and the publicity they receive, with the sole objective of maximizing their own profits. Because managerial decisions directly impact all the stakeholder groups, managers can be viewed as not only the agents of shareholders but also the agents of other stakeholders (Jones 1995). Consistent with these arguments, studies indicate that companies resort to corporate social responsibility in order to hide their manipulating reported earnings (Prior, Surroca, and Tribó 2008, Chih, Shen, and Kang 2008, Petrovits 2006). To test this view, this study proposes the following hypothesis which is based on managers' opportunistic incentives:

H1A: There is a negative relationship between CSD and earnings quality. 
Based on the stakeholder theory (Freeman 1984), some researchers suggest that corporate social responsibility is part of a long-run perspective of economic gain that may not be financially measurable but may provide a valuable asset for future profitability, and eventually enhances the financial status of firms (Carroll 1999, Davis 1960, Choi, Lee, and Park 2013). Davis (1960) suggests that taking care of social responsibilities and financial status is a necessary activity for firms, for long-run sustainability. Accordingly, Choi et al. (2013) propose that a firm's quality of earnings needs to be commensurate with its corporate social responsibility activities to meet the needs of the stakeholders. Studies also indicate that firms' engagement with corporate social responsibility mitigates earnings management (Scholtens and Kang 2013, Kim, Park, and Wier 2012). Based on this long-run perspective, the following hypothesis is proposed:

H1B: There is a positive relationship between CSD and earnings quality.

Vietnamese listed firms have high state ownership and control as their institutional environment. This is partly attributed to the fact that most of these now listed firms were previously SOEs. The average level of state ownership of listed firms in this study is 27 per cent. State ownership in firms assists the government to enact social objectives through firms, and this study considers the impact of ownership structure on the CSD practices-earnings quality relationship.

State managers have less pressure to manipulate firms' earnings because their financial incentive structure is not connected with firms' earnings (Wang and Yung, 2011). The government's requirement is to obtain a guaranteed return from firms with state ownership. The government is also prepared to provide additional funds to those firms (Ding, Zhang, and Zhang 2007, Jiang and Habib 2009, Wang and Yung 2011). As a result, firms with higher state ownership have fewer incentives to disclose more information because increasing state ownership in firms provides greater access to firms' information on (state) demand (Jiang and 
Habib 2009). Another reason is that firms with higher state ownership are discouraged from disclosing more information because of political constraints (Ghazali and Weetman 2006). There should, therefore, be a negative interaction between state ownership and earnings quality in determining a firm's CSD practices.

H2: More state ownership will weaken the relationship between earnings quality and CSD.

Firms with higher foreign ownership are required to increase informative disclosures in order to raise and retain foreign investment (Boubakri et al. 2007, Haniffa and Cooke 2005). Strengthening the supply of capital from foreign investors is crucial in the development of many emerging capital markets (Bokpin and Isshaq 2009, Mangena and Tauringana 2007). Firms with higher foreign ownership are considered to be associated with better monitoring and are thus expected to reduce the ability of insiders to manipulate earnings for private purposes (Doidge 2004, Hail and Leuz 2009). Foreign ownership also has a positive and significant relation with the level of information transparency and in the long term can stimulate the growth of a firm, capital markets, and a country as a whole (Ho, Tower, and Taylor 2013).

In the Vietnamese context, the government has taken various steps to increase foreign ownership by reducing restrictions on foreign investment. The foreign ownership maximum limitation was increased from 20 per cent in 2000 to 30 per cent in 2003 and finally to 49 per cent in 2005 for listed firms except for banks. The majority of foreign owners are from developed countries that have stronger financial regulatory systems. These foreign investors are more likely to be aware of the importance of financial and non-financial information in investment decision making. Therefore, we propose the following hypothesis:

H3: More foreign ownership will strengthen the relation between earnings quality and CSD.

\section{Measures and the sample}

\section{Earnings quality measures}


This study constructed an standardised aggregate earnings quality score based on four accounting measures of earnings attributes used in prior studies (Francis et al. 2004, Boonlert-U-Thai, Meek, and Nabar 2006), namely, accruals quality, earnings persistence, earnings predictability, and earnings smoothness. Using the autoregressive approach, this study uses these four earnings quality measures as specific to firms and each quality measure is estimated by rolling over the specific measure over a five-year period. Because the accruals quality measure requires lagged and forward data, a firm is included in the year $\mathrm{t}$ sample if data are available for seven years from years $t-5$ to $t+1$.

\section{Accruals quality}

Accruals quality (AQ) in this study is based on the widely used Dechow and Dichev (2002) statistical calculation technique, where it is measured by relating total current accruals to cash flows from operations. The extent to which current accruals map to cash flows from operations indicates higher earnings quality. Therefore, lower standard deviation of residuals represents higher earnings quality. AQ as the standard deviation of residuals $\left(\varepsilon_{\mathrm{j}}\right)$ is obtained from the following regression:

$\mathrm{TCA}_{\mathrm{j}, \mathrm{t}}=\varphi_{0}+\varphi_{1} \mathrm{CFO}_{\mathrm{j}, \mathrm{t}-1}+\varphi_{2} \mathrm{CFO}_{\mathrm{j}, \mathrm{t}}+\varphi_{3} \mathrm{CFO}_{\mathrm{j}, \mathrm{t}+1}+\varepsilon_{\mathrm{j}, \mathrm{t}}$

Where $\mathrm{TCA}_{\mathrm{j}, \mathrm{t}}=$ firm j's total current accruals in year $\mathrm{t}\left(\Delta \mathrm{CA}_{\mathrm{j}, \mathrm{t}}-\Delta \mathrm{CL}_{\mathrm{j}, \mathrm{t}}-\Delta \mathrm{Cash}_{\mathrm{j}, \mathrm{t}}+\right.$ $\left.\Delta \mathrm{STDEBT}_{\mathrm{j}, \mathrm{t}}\right) ; \mathrm{CFO}_{\mathrm{j}, \mathrm{t}}=$ firm $\mathrm{j}$ 's cash flow from operations in year $\mathrm{t} ; \Delta \mathrm{CA}_{\mathrm{j}, \mathrm{t}}=$ firm $\mathrm{j}$ 's change in current assets between year $\mathrm{t}-1$ and year $\mathrm{t} ; \Delta C \mathrm{~L}_{\mathrm{j}, \mathrm{t}}=$ firm $\mathrm{j}$ 's change in current liabilities between year $\mathrm{t}-1$ and year $\mathrm{t} ; \Delta \mathrm{Cash}_{\mathrm{j}, \mathrm{t}}=$ firm j's change in cash between year $\mathrm{t}-1$ and year $\mathrm{t}$; and $\triangle \mathrm{STDEBT}_{\mathrm{j}, \mathrm{t}}=$ firm $\mathrm{j}$ 's change in debt in current liabilities between year $\mathrm{t}-1$ and year $\mathrm{t}$. All variables in equation (1) are deflated by firm j's total assets in year t-1.

\section{Earnings persistence}


Earnings persistence (PERSIS) is the extent to which current period earnings reflect future period earnings. Following Francis et al. (2004), PERSIS is measured as the negative of the slope coefficient estimate, $\phi_{1, \mathrm{j}}$, from the following model:

$\operatorname{Earn}_{\mathrm{j}, \mathrm{t}}=\phi_{0, \mathrm{j}}+\phi_{1, \mathrm{j}} \operatorname{Earn}_{\mathrm{j}, \mathrm{t}-1}+\mathrm{v}_{\mathrm{j}, \mathrm{t}}$

Where Earn $_{\mathrm{j}, \mathrm{t}}=$ firm's $\mathrm{j}$ net income before extraordinary items in year $\mathrm{t}$. All variables in equation (2) are deflated by firm j's total assets in year t-1. Larger values (i.e., less negative) of PERSIS indicate less earnings quality.

\section{Earnings predictability}

Earnings predictability (PREDICT) is the ability of earnings to predict itself (Lipe 1990). Our measure of PREDICT is the standard deviation of the residuals $\left(\mathrm{v}_{\mathrm{j}}\right)$ from equation (2), following Francis et al. (2004). Larger values of PREDICT imply less earnings quality.

\section{Earnings smoothness}

This study adopts the measure of earnings smoothness (SMOOTH) in Francis et al. (2004) as the ratio of firm i's standard deviation of net income before extraordinary items scaled by beginning total assets, to its standard deviation of cash flows from operations scaled by beginning total assets. Larger values of SMOOTH imply less earnings quality.

\section{The standardised aggregate earnings quality score}

Based on the four individual earnings quality measures (AQ, PERSIS, PREDICT, SMOOTH), this study constructs a standardized aggregate earnings quality score. Based on how the individual earnings attributes are ascertained, the larger the value of the individual earnings quality measure, the lower the earnings quality. Following Leuz, Nanda, and Wysocki (2003), the four individual earnings quality values are arranged in descending order, so that a higher ranked value now represents higher earnings quality. The standardized aggregate earnings quality score of a firm is computed by averaging the firm rankings for the four individual earnings quality measures. 


\section{CSD measures}

This study constructs a three-dimensional CSD index where one dimension is the quantity of CSD, and other two relate to disclosure type quality and disclosure item quality. A content analysis of annual reports is used to measure the quantity of CSD. To ensure consistency, only one of the authors coded all the annual reports, and a set of basic coding rules was constructed to ensure reliability and validity. This was repeated after two weeks (Haji 2013) in order to avoid the possibility that the first and the second scoring might influence each other (Weetman and Ghazali 2006). As a second step to establish inter-rater reliability, another author coded ten randomly selected annual reports and found no significant difference between the two coders.

This study uses the Global Reporting Initiative (GRI) 3.1 index, the social indicators in particular, to measure CSD practices in Vietnam. The social indicators in the GRI 3.1 index identify key performance aspects surrounding labor practices, human rights, society, and product responsibility. They consist of four aspects, including 15 items of labor practices and decent work indicators (LA1 to LA15), 11 items of human rights indicators (HR1 to HR11), 10 society indicators (SO1 to SO10), and 9 product responsibility indicators (PR1 to PR9). The GRI framework items are used for CSD in this study because those reporting items have been standardized across the firms and objectives, regardless of their geographical location (Adams 2002).

\section{Measuring disclosure quantity}

In order to measure the disclosure quantity, this study examines the different items in the checklist using binary scores. This is consistent with CSD studies in emerging capital markets (Khan, Muttakin, and Siddiqui 2013, Haji 2013, Haniffa and Cooke 2005). The disclosure of an item within the checklist in the annual reports is scored as "1", while the non-disclosure of an item within the checklist in the annual reports is scored as "0". 


\section{Measuring disclosure item quality and disclosure type quality}

The binary approach to measuring disclosure quantity has been criticized because it assumes that all items are equally important (Barako, Hancock, and Izan 2006). Lu and Abeysekera (2014) create a combined disclosure quality measure using the importance of reporting items and the importance of different disclosure types. This study extends Lu and Abeysekera's (2014) study by obtaining perceptions from 652 stakeholders about the importance of reporting items, rather than the 12 stakeholders used in that study.

The two aspects of disclosure quality (i.e., disclosure type quality and disclosure item quality) in this CSD index are measured by surveying four stakeholder groups (employees, lawyers and regulators, local communities, and customers) to obtain their perceptions on disclosure type preference (i.e., narrative; monetary quantification; numerical quantification; both monetary and numerical), and about disclosure reporting items (i.e., items in the social indicators of the Global Reporting Initiative 3.1). The types of disclosure are narrative, monetary quantification (i.e. the amount of money), numerical quantification (i.e. the number or statistics), both monetary and numerical. The social indicators in the GRI 3.1 index consist of four aspects: labour practices, human rights, society, and product responsibility. For the type of items, if the same item is disclosed more than once with different types, an average score is computed to allow each item to contribute to the overall results.

The questionnaires were delivered by hand to the target stakeholder groups. ${ }^{1}$ Different stakeholder groups received different versions of the questionnaire. The social stakeholders included employees (labor stakeholders) who responded to the questionnaire for aspects of labor practices and decent work; customers (product stakeholders) who responded to the questionnaire for product responsibility aspects; members of local communities (society stakeholders) who responded to the questionnaire for societal aspects; and lawyers and

\footnotetext{
${ }^{1}$ Given the limited number of pages allowed in the manuscript, the questionnaires are available upon request (See the Supplementary Material, available online).
} 
regulators (human rights stakeholders) who responded to the questionnaire for human rights aspects. The questionnaire has a scale of zero (unimportant) to 10 (the most important), making it an 11-point scale. This increases the variance of responses obtained and makes the results more reliable (Dawes 2002, Hartley and Betts 2010). The stakeholder-specific groups were requested to rate each item from zero to 10 based on their perceptions of how important the item was to them and how the items should be disclosed. They were also asked for their perceptions on the importance of four disclosure types (i.e., narrative, monetary quantification, numerical quantification, both monetary and numerical) for each item based on a rating scale from zero to 10 .

The weight for a particular item is calculated by summing the integer values assigned to the item and then dividing the total by the number of individuals who responded to the item. Similarly, the level of importance for each type (i.e., narrative, monetary quantification, numerical quantification, both monetary and numerical) of a particular item is calculated by summing the integer values assigned to each particular type of disclosure for each item and then dividing the total by the number of individuals who responded to this type. A mean score is used to summarize the response scores within a specific stakeholder group.

\section{The stakeholder-driven, three-dimensional CSD index}

The stakeholder-driven, three-dimensional CSD index is computed for each firm using the following equation:

$$
C S D_{-} \text {INDEX }_{j}=\frac{\sum_{i=1}^{n} \text { Quantity }_{i}^{*} \text { ItemQuality }_{i}^{*} \text { TypeQuality }_{i}}{\max \left(\text { SCORE }_{i}\right)}
$$

where CSD_INDEX $X_{j}=$ a stakeholder-driven, three-dimensional index of firm $j$; Quantity $_{i}=$ the disclosure or non-disclosure of an item $i$ with regard to this item's disclosure type in firm $j$ ItemQuality $_{i}=$ the weight of the item i disclosed; TypeQuality ${ }_{i}=$ the weight for the type (i.e., narrative, monetary quantification, numerical quantification, or both monetary and 
numerical) of the item $\mathrm{i}$ disclosed; $n=$ the number of items in the checklist; and $\max (\mathrm{SCORE})=$ the maximum score of three disclosure dimensions for a given firm: disclosure quantity score * disclosure type quality score *disclosure item quality score.

\section{Control variables}

This study controls for firm characteristics such as return on assets (ROA), auditors (AUDIT), state ownership (STATE), foreign ownership (FOREIGN), and stock exchange location (STOCK_EX), which influence CSD (e.g., Purushothaman et al. 2000, Cormier, Ledoux, and Magnan 2011, Vu, Tower, and Scully 2011a, Vu 2012).

Prior studies show that female directors are active in contributing to social issues, and are more likely to sponsor charities and have stronger relationships with surrounding communities, shareholders, and other stakeholder groups (Siciliano 1996, Williams 2003, Bernardi and Threadgill 2010). Furthermore, recent literature shows that female directors are associated with higher earnings quality (Gul, Hutchinson, and Lai 2013, Srinidhi, Gul, and Tsui 2011). Hence, this study also uses female directors (FEMALE) as a control variable in examining the relationship between earnings quality and CSD.

\section{The relationship between earnings quality and CSD}

The hypotheses $1 \mathrm{~A}$ and $1 \mathrm{~B}$ regarding the effect of CSD on earnings quality are tested using an OLS estimator. The regression function is:

$$
\text { CSD_INDEX }{ }_{i}=\alpha_{0}+\alpha_{1} E Q_{i}+\sum \gamma_{j, i} \text { controlvariables }_{i}+\varepsilon_{i}
$$

In order to test the hypotheses 2 and 3 about the effects of state and foreign ownership on CSD-earnings quality relation, the following regression is used:

$$
\begin{aligned}
& C S D D_{-} I N D E X_{i}=\beta_{0}+\beta_{1} E Q_{i}+\beta_{2} E Q_{i} \times S T A T E_{i}+\beta_{3} E Q_{i} \times F O R E I G N_{i} \\
& +\Sigma \eta_{j, i} \text { Controlvariables } s_{i}+\varepsilon_{i}
\end{aligned}
$$

where CSD_INDEX $\mathrm{i}_{\mathrm{i}}=$ firm i's stakeholder-driven, three-dimensional CSD index; $E Q_{i}=$ firm i's standardised aggregate earnings quality score, calculated as the average rank across 
the four individual measures (accruals quality, earnings persistence, earnings predictability, and earnings smoothness); and $\mathrm{i}=1, \ldots, 133$ firms.

\section{The sample}

The sample consists of all Vietnamese listed firms for which the required data items are available, except for banks and other financial industry firms. This study examines the annual reports during the year ended 31 December 2010 to capture the quality of CSD of Vietnamese listed firms. The 2010 year was chosen in this study as on 15 January 2010, the Ministry of Finance in Vietnam issued the Guidance for Information Disclosure on Stock Exchange with the aim of providing guidance to enhance the disclosure practices of Vietnamese listed firms. The individual earnings quality attributes are estimated by using five-year rolling windows from 2006 to 2010 to generate the 2010 earnings quality measures of the sample, similar to Francis et al. (2008). Accruals quality is one of four earnings quality measures in this study. Because estimating this measure requires lagged and forward data, this study generated the 2010 accruals quality measure by using the financial statement data items for seven years, from 2005 to 2011.

The financial statement data items are extracted from the websites for Ho Chi Minh stock exchange (HOSE) and Hanoi stock exchange (HNX) for the fiscal years 2005 to 2011. The year 2005 is when HNX came into operation. The final sample, with all required data available, includes 133 firms.

\section{The results}

\section{Descriptive statistics}

Table 1, Panel A, shows the ratings awarded by the employees to the various reporting items concerning the labor aspect (LA). The highest mean score for those reporting items was 7.47 and the lowest was 6.44 , out of a maximum possible score of 10 . In analyzing the disclosure types for the 15 reporting items of the labor aspect, employee respondents rated the highest 
scores for items with numerical disclosures $(60 \%$ or 9 items $)$, and for reporting items with both monetary and numerical disclosures ( $40 \%$ or 6 items). Employees assigned the lowest scores for the items with monetary disclosures $(73.33 \%$ or 11 items), and for the items with narrative disclosures $(26.67 \%$ or 4 items).

Table 1, Panel B, provides the ratings awarded by lawyers and regulators to the various information items about the human rights aspect (HR). The highest mean score for the information items was 8.19 and the lowest was 6.38. Related to the disclosure types, out of 11 items in the human rights aspect, lawyers and regulators assigned the highest scores for items with numerical disclosures $(81.82 \%$ or 9 items), and for items with both monetary and numerical disclosures $(18.18 \%$ or 2 items). They assigned the lowest scores for items with narrative disclosures $(90.91 \%$ or 10 items) and items with monetary disclosures $(9.09 \%$ or 1 item).

Table 1, Panel C, presents the ratings assigned by the members of local communities for the various reporting items having to do with the societal aspect (SO). The highest mean score for the reporting items was 7.92 and the lowest was 6.22 . Related to the disclosure types, interestingly, out of 10 items in the societal aspect, local communities assigned the highest scores for all 10 items with both monetary and numerical disclosures. They assigned the lowest mean scores to all 10 items with narrative disclosures.

Table 1, Panel D, shows the ratings awarded by customers for the various reporting items about the product aspect (PR). The highest mean score for the reporting items was 8.08 and the lowest was 6.62. Related to the disclosure types, out of 9 items in the product aspect, customers assigned the highest scores for the items with both monetary and numerical disclosures $(88.89 \%$ or 8 items), and one item with narrative disclosures $(11.11 \%)$. They assigned the lowest scores to the items with narrative disclosures (55.56\% or 5 items), monetary disclosures $(33.33 \%$ or 3 items), and one item with numerical disclosures $(11.11 \%)$. 
$<$ Insert Table 1 about here $>$

Table 2 presents the descriptive statistics. As shown in Table 2, the sample mean value of $E Q$ is 67.0. A higher $E Q$ implies a higher level of earnings quality. The AQ measure has a mean value of 0.06 . PERSIS, which captures (the negative of) the extent to which an earnings innovation remains in the series, has a mean value of -0.44 . PREDICT has a mean value of 0.07. Finally, SMOOTH, which captures the variability of income relative to the variability of cash flows, has a mean value of 0.48 .

The stakeholder-driven, three-dimensional CSD index (CSD_INDEX) ranged from 3 per cent to 23 per cent with a mean of 10 per cent, which reveals that CSD of listed firms in the sample is low. This is because CSD practices are relatively new in Vietnam (Vu, Tower, and Scully 2011a). The findings are consistent with the study by Vu, Tower, and Scully 2011a), which examines the quantity of voluntary disclosure, including social disclosure, in Vietnam. Four different social aspects of disclosure, i.e., labor (LAD_INDEX), society (SOD_INDEX), product (PRD_INDEX), and human rights (HRD_INDEX), have mean scores of 17 per cent, 4 per cent, 16 per cent, and 1 per cent, respectively ${ }^{2}$.

The average percentage of state ownership in our sample is 27 per cent (with a range of zero to 79.07 per cent), and this represents a highly concentrated ownership by the state. Because of the 49 per cent maximum foreign ownership ceiling in Vietnamese listed firms, the average percentage of foreign ownership is quite low (12 per cent with a range of zero to 49 per cent). The average of FEMALE is approximately 14 per cent and there are no allfemale boards.

$$
<\text { Insert Table } 2 \text { about here }>
$$

\footnotetext{
${ }^{2}$ The stakeholder-driven, three-dimensional labour aspect disclosure index (LAD_INDEX) is computed for each firm using the equation similar to the equation of calculating the stakeholder-driven, three-dimensional CSD index but measures only with labour aspect. This is similar to measure SOD_INDEX, PRD_INDEX and HRD_INDEX.
} 
Four individual earnings attribute measures (AQ, PERSIS, PREDICT, and SMOOTH) are highly correlated, with coefficients of more than 0.3 (results are not tabulated but are available upon request), suggesting reasonable factorability (Hair 1998). Additionally, the Kaiser-Meyer-Olkin measure of sampling adequacy is 0.76 for the overall test and more than 0.7 for each earnings attribute measure (not tabulated), above the commonly recommended value of greater than 0.5 (Hair 1998). The Bartlett's test of sphericity is significant $\left(\chi^{2}(6)=\right.$ 235.82, $\mathrm{p}<0.000$ ). Adopting the 'eigenvalue-greater-than-one rule' (Hair 1998), this study reduces the number of factors to one because there is only one factor with eigenvalue of 2.68 (not tabulated). Factor analysis suggests that a single factor represents these four earnings attribute measures, and they accounted for 66.90 per cent of the total variance, above the criterion of 60 per cent (Hair 1998). Hence, it is proper to combine the four earnings attributes measures into a single standardized aggregate measure of earnings quality. This approach is similar to Leuz et al. (2003), who used factor analysis to clarify the combination of four individual earnings management measures into a standardized aggregate earnings management score.

\section{Regression analyses and findings}

This study checked for the variance inflation factor (VIF) for the regression models. Because the individual values of VIF are less than 10 for all the regression models, multicollinearity does not seem to be a problem for the test models in this study (Gujarati and Porter 2009).

To confirm whether or not heteroscedasticity exists, this study used the Breush-Pagan test. The $p$-values were found to be significant $(\mathrm{p}<0.04)$, thus the null hypothesis is rejected, indicating the presence of heteroscedasticity. To correct the possible influence of heteroscedasticity, OLS regression with heteroscedasticity robust standard errors (White 1980) was used to test the effect of earnings quality (EQ) on CSD (CSD_INDEX), and the 
moderating effect of the ownership structure (i.e., EQ*FOREIGN and EQ*STATE) on the relationship between earnings quality and CSD.

Table 3 provides the results for the tests of hypotheses $1 \mathrm{~A}, 1 \mathrm{~B}, 2$, and 3 , using CSD_INDEX as the dependent variable. The independent variables were EQ, EQ*FOREIGN, and EQ*STATE. Two models examined the relationship between the dependent variable and independent variables and the results are reported in Table 3.

Column (1) of Table 3 examines the relationship without interacting variables in equation (4). In that model, the coefficient estimate of the standardized aggregate earnings quality (EQ) is positive and significant $\left(\alpha_{1}=0.0003, \mathrm{p}=0.079\right)$. This indicates that firms that report high quality earnings also have high CSD. This result confirms hypothesis $1 \mathrm{~B}$ (i.e., there is a positive relationship between earnings quality and CSD).

Column (2) of Table 3 adds the interaction variables between STATE and EQ and between FOREIGN and EQ in the model (equation (5)). They are included to reveal the effects of state and foreign ownership on the relationship between earnings quality and CSD. The coefficient of EQ is still positive and significant $(\alpha 1=0.0008, p=0.007)$, while the coefficient of the interaction variable between STATE and EQ is negative and significant (0.0015, p-value of 0.034) as shown in Column (2) of Table 3, which confirms hypothesis 2 (i.e., more state ownership will weaken the relationship between earnings quality and stakeholder-relevant CSD) suggesting that firms with more state ownership and with high earnings quality, are likely to report less stakeholder-relevant CSD. After adding the interaction variable of STATE and EQ, the results show that it is likely that EQ, and STATE, have substitutive effect on stakeholder-relevant CSD. When the earnings quality becomes low in a state-owned company, the state-owned company is likely to decrease the stakeholder-relevant CSD. Additionally, the estimated coefficient of the interaction term of FOREIGN and EQ is negative (-0.0012) but insignificant ( $\mathrm{p}$ value $=0.295)$, suggesting that 
foreign ownership does not have an effect on the relationship between earnings quality and CSD, which rejects hypothesis 3 (i.e., more foreign ownership strengthens the relation between earnings quality and CSD). This result is consistent with the study conducted by Choi et. al. (2013) in Korea, which documents that the presence of foreign investors does not influence the relationship between earnings quality and corporate social responsibility ratings. There are two possible reasons for this. First, it could be that foreign investors may experience difficulties in controlling managerial behavior because of the geographical differences, language, and culture (Xiao and Yuan 2007, Choi, Lee, and Park 2013). Second, the 49 per cent maximum foreign ownership ceiling also can limit the power of foreign investors to influence the reporting behavior of the firm ( $\mathrm{Vu}$, Tower, and Scully 2011a).

$<$ Insert Table 3 about here $>$

The results for control variables shown in Table 3 indicate a significant positive association ( $\mathrm{p}$ values $<0.003$ ) between AUDIT and CSD_INDEX, which suggests that the quality of CSD is higher for firms that are audited by the big four audit firms, consistent with prior studies (Craswell 1992, Inchausti 1997, Uwuigbe and Egbide 2012). Return on asset (ROA) has positive and significant coefficients, suggesting that firms with better financial performance are likely to make more CSD, as is consistent with the existing literature (Khan et al., 2013; Lu and Abeysekera, 2014; Haniffa and Cooke 2005). The STOCK_EX is positively and significantly ( $\mathrm{p}$ values $<0.0001$ ) correlated with $C S D \_I N D E X$, which indicates that firms listed on HOSE are likely to engage in significantly more CSD than firms listed on HNX. This is consistent with $\mathrm{Vu}$ (2012), who examined determinants of voluntary disclosure for Vietnamese listed firms. FOREIGN is not significantly related to CSD_INDEX in column (1), which is consistent with prior studies (Said, Hj Zainuddin, and Haron 2009, Haniffa and Cooke 2005). In the context of this study, this is probably because the 49 per cent maximum foreign ownership ceiling limits the power of foreign investors to influence the reporting 
behavior of the firm (Vu, Tower, and Scully 2011a). Similarly, STATE is not significantly related to CSD_INDEX in column (1), consistent with the findings of Naser et al. (2006) and Lu and Abeysekera (2014). This may reflect the business models in a country like Vietnam where shares of most listed firms are owned by the government. If the government owns shares in most firms listed on the stock exchange, these firms will have little incentive to make voluntarily disclosures, including CSD. In column (2) of Table 3, although FOREIGN is not significantly related to CSD, STATE is positively and moderately significant (p value = 0.063) with CSD_INDEX. FEMALE is positively significant ( $\mathrm{p}$ values $=0.01$ ) with CSD_INDEX. This is consistent with prior studies (Zhang, Zhu, and Ding 2013, Post, Rahman, and Rubow 2011).

\section{Additional analysis and robustness tests}

\section{The standardized aggregate earnings quality score without accruals quality}

Wysocki (2006) expresses concerns about using accruals quality (AQ) as an attribute to measure earnings quality because this attribute can drive results of earnings quality, subjugating other attributes. More specifically, Wysocki finds that current cash flows are simultaneously significantly and negatively related to current accruals. Wysocki notes that although there are other dimensions in a composite earnings quality measure, the accruals quality is the most discerning and damaging dimension. Guided by Wysocki, to ensure that results in this study are not simply driven by $A Q$, all tests are repeated with an alternative earnings quality by averaging the firm rankings for the three standardized aggregated individual earnings attributes measures (EQ_3ATTRI: earnings persistence, earnings predictability, and earnings smoothness) only. The results are presented in Table 4.

$<$ Insert Table 4 about here $>$

The results as shown in Table 4 are similar to those in Table 3 and hence support hypothesis 1B (i.e., there is a positive relationship between CSD and earnings quality), 
confirming hypothesis 2 (i.e., more state ownership will weaken the relationship between earnings quality and CSD), but rejecting hypothesis 3 (i.e., more foreign ownership strengthens the relation between earnings quality and CSD). The exception is that the effect of STATE on CSD_INDEX in column (2) of Table 4 is not statistically significant, with a pvalue of 0.13 . Additionally, the impact of earnings quality on CSD in column (1) of Table 4 is more significant than that of Table $3(p=0.037$ vs. $p=0.079)$ whereas the interaction term of state ownership and earnings quality in Table 4 is less significant than that in Table 3 (p= 0.077 vs. $\mathrm{p}=0.034)$. Overall, these results show that findings in this study are not simply driven by accruals quality and are generally consistent when using alternative proxies for earnings quality.

\section{Earnings quality and labor and society aspects of disclosure quality}

Pham (2011) documents that managers of Vietnamese firms focus greatly on charity and employment matters, such as health and safety and the working environment, in corporate social policies. Choi et al. (2013) also state that these two aspects, society and labor, help to counter adverse public opinions and ease strain firms have with the government and labor unions. Following Choi et al. (2013), this study constructed another social disclosure index consisting of two aspects, i.e., society (10 items) and labor (15 items) only, rather than the four aspects (i.e., society, labor, human rights, and product responsibility) included in the main model. The results are provided in Table 5. They are consistent with the main findings in Table 3.

\section{$<$ Insert Table 5 about here $>$}

\section{Endogeneity}

The main results provide evidence of a positive relationship between earnings quality and CSD. One concern here is that the relationship may be endogenous, potentially biasing the results. Because the sample size in this study is quite small (133 firms), to address the 
endogeneity issue, this study estimates CSD_INDEX and EQ regressions using the limitedinformation maximum likelihood (LIML) method. ${ }^{3}$

We use the length of the operating cycle (LOG.OC), measured as the log of the sum of the firm's days accounts receivable and days inventory, and the incidence of net loss realizations (LOSS), computed as the number of years where the firm reported a loss as instruments for EQ in both models in equations (4) and (5) in order to test for reverse causality - that is, CSD influences earnings quality. The study assumes that these innate variables do not affect CSD (at least directly) but do affect EQ. Francis et al. (2005) also found that these two variables as innate factors of a firm influence earnings quality.

The LIML generates instrumental variables, and then tests whether those instrumental variables are weakly correlated with the suspected endogenous variable, earnings quality. Instrumental variables help to establish the causal effect. The null hypothesis in the LIML is that a weak correlation between the instrumental variables (instruments) and the earnings quality (suspected endogenous variable) indicates that earnings quality is endogenous.

\section{$<$ Insert Table 6 about here $>$}

As shown in Panel A of Table 6 related to the model examining the relationship without interacting variables in equation (4), the $F$ statistic is 10.74 , which is above the often-used threshold of 10 (Staiger and Stock 1997). This indicates that this model contains one endogenous regressor (Staiger and Stock 1997). Additionally, Stock and Yogo (2005) show that a set of instruments is weak if a Wald test at the 5\% level can have an actual rejection rate of no more than $10 \%, 15 \%, 20 \%$, or $25 \%$. Therefore, Panel A of Table 6 shows that here it can reject the null hypothesis that the instruments are weak, since the $F$ statistic of $10.74>$ 8.68 (the critical value for a rejection rate of at most $10 \%$ ). On the basis of this test, the model

\footnotetext{
${ }^{3}$ We obtain consistent results using two-stage least squares (2SLS) estimation (See Table S1, available online).
} 
in equation (4) of this study does not have a weak-instrument problem. Earnings quality in the OLS model is an independent and also an exogenous variable.

In contrast, Panel B of Table 6 shows that the model in equation (5) of this study has a weak-instrument problem. The $F$ statistic is 6.17 , which is below the threshold of 10 (Staiger and Stock 1997). In addition, the $F$ statistic of $6.17<8.68$ (the critical value for a rejection rate of at most 10\%), which cannot reject the null hypothesis of weak instruments. Therefore, this study relies on the OLS results for the model in equation (5).

To verify the validity of the instruments in the model in equation (4), this study does a test for over-identifying restrictions. The results show that the p-values of Anderson-Rubin's statistic and Basmann's statistic are 0.797 and 0.804, respectively. This indicates that instruments in this model are not correlated with the error of the main regression. Therefore the LIML estimators are superior to the OLS estimators in the model in equation (4).

This study uses the same set of control variables as in Table 3 for CSD in the LIML regression. The results reported in Table 7, using the superior LIML estimators for the model examining the relationship without interacting variables in equation (4), support the primary finding in this study that earnings quality positively impacts CSD.

$<$ Insert Table 7 about here $>$

\section{Conclusions}

The paper explores the relationship between CSD and earnings quality of Vietnamese listed firms and also examines the effects of state and foreign ownership on the relationship between CSD and earnings quality. The results support hypothesis 1B but not hypothesis $1 \mathrm{~A}$, meaning that the long-term perspective argument dominates the managerial opportunism hypothesis in the relationship between earnings quality and CSD. Specifically, our findings suggest that earnings quality is positively and significantly associated with CSD. We also find that the relationship between earnings quality and CSD is weakened as the percentage of 
shares held by government increases, which confirms hypothesis 2 . Meanwhile, the presence of foreign investors does not influence the association between earnings quality and CSD, which rejects hypothesis 3 . Robustness tests also confirm these results.

In addition to the contribution from this study noted in the Introduction section, to the best of our knowledge, this is the first concerted attempt to examine the relationship between earnings quality and CSD for the small and newly emerging market of Vietnam. Vietnam is one of the lowest ranked countries in protecting investors among the Southeast Asian countries. In addition, the empirical results which demonstrate the current CSD practices of Vietnamese listed firms and stakeholders' perceptions to CSD, will benefit regulators in better understanding firms' CSD practices and stakeholders' expectations. The evidences can be references for Vietnamese authority to improve the current guidelines on the stakeholderrelevant CSD of Vietnamese listed firms. Furthermore, despite becoming a fast-growing economy with increasing prominence in the Asia-Pacific, the Vietnamese economy is still relatively under-examined, particularly with regard to its accounting and finance aspects $(\mathrm{Vu}$, Tower, and Scully 2011b). This study reflects an attempt to fill the gap in the literature by extending the understanding of firms earnings quality, stakeholder-relevant CSD, and the moderating effect of ownership structure in the Vietnamese context.

We acknowledge that the sample size and confining the analysis of disclosure to 2010 year may limit the generalizability of results. We chose the survey and annual reports analysis to obtain clarity about the role Circular No. 09/2010/TT-BTC dated January 15, 2010 play in the transparency of disclosure of listed firms and stakeholders' perspectives. The requirement of five years' rolling data to measure accruals quality while the two Vietnamese stock exchanges with HOSE established in 2010 and HNX established in 2005, also influenced the year of choice in the study. Studies document that firms' disclosure policies appear to remain relatively constant over time (Muttakin and Khan 2013, Healy, Palepu, and 
Sweeney 1995). A longitudinal study where disclosure policies have varied within the time period can provide different insights. This study found the Audit firm selection (Big four versus otherwise) and female board representation are likely to increase stakeholder-relevant CSD, can bring forth a future study to examine the influence of other internal and external corporate governance measures on corporate social disclosure.

\section{References}

Adams, Carol A. 2002. "Internal organisational factors influencing corporate social and ethical reporting: Beyond current theorising." Accounting, Auditing \& Accountability Journal 15 (2):223-250. doi: doi:10.1108/09513570210418905.

Barako, Dulacha G., Phil Hancock, and H. Y. Izan. 2006. "Factors Influencing Voluntary Corporate Disclosure by Kenyan Companies." Corporate Governance: An International Review 14 (2):107-125. doi: 10.1111/j.1467-8683.2006.00491.x.

Bernardi, R., and V. Threadgill. 2010. "Women Directors and Corporate Social Responsibility." Electronic Journal of Business Ethics and Organization Studies 15 (2):15-21.

Bokpin, Godfred A., and Zangina Isshaq. 2009. "Corporate governance, disclosure and foreign share ownership on the Ghana Stock Exchange." Managerial Auditing Journal 24 (7):688-703. doi: 10.1108/02686900910975387.

Boonlert-U-Thai, Kriengkrai, Gary K. Meek, and Sandeep Nabar. 2006. "Earnings attributes and investor-protection: International evidence." The International Journal of Accounting 41 (4):327.

Boubakri, Narjess, Jean Claude Cosset, Omrane Guedhami, and Mohammed Omran. 2007. "Foreign Investor Participation in Privatizations: Does the Institutional Environment Matter?" Journal of Financial Research 30 (1):129-146. doi: 10.1111/j.1475-6803.2007.00206.x.

Carroll, Archie B. 1999. "Corporate Social Responsibility: Evolution of a Definitional Construct." Business \& Society 38 (3):268-295. doi: 10.1177/000765039903800303.

Chih, Hsiang-Lin, Chung-Hua Shen, and Feng-Ching Kang. 2008. "Corporate Social Responsibility, Investor Protection, and Earnings Management: Some International Evidence." Journal of Business Ethics 79 (1/2):179-198. doi: 10.1007/s10551-007-9383-7.

Choi, Bo Bae, Doowon Lee, and Youngkyu Park. 2013. "Corporate Social Responsibility, Corporate Governance and Earnings Quality: Evidence from Korea." Corporate Governance: An International Review 21 (5):447-467. doi: 10.1111/corg.12033.

Cormier, Denis, Marie-Josée Ledoux, and Michel Magnan. 2011. "The informational contribution of social and environmental disclosures for investors." Management Decision 49 (8):1276-1304. doi: $10.1108 / 00251741111163124$. 
Craswell, A. T. 1992. "Discretionary Disclosure of Reserves by Oil and Gas Companies: An Economic Analysis." Journal of Business Finance \& Accounting 19 (2):295-308. doi: 10.1111/j.1468-5957.1992.tb00626.x.

Davis, Keith. 1960. "Can Business Afford to Ignore Social Responsibilities? ." California Management Review (pre-1986) 2 (3):70.

Dawes, John. 2002. "Five Point vs Eleven Point Scales: Does it make a difference to data characteristics?" Australasian Journal of Market Research 10 (1):39-47. doi: citeulikearticle-id:2576444.

Dechow, Patricia M., and Ilia D. Dichev. 2002. "The Quality of Accruals and Earnings: The Role of Accrual Estimation Errors." The Accounting Review 77 (s-1):35-59. doi: 10.2308/accr.2002.77.s-1.35.

Ding, Yuan, Hua Zhang, and Junxi Zhang. 2007. "Private vs State Ownership and Earnings Management: evidence from Chinese listed companies." Corporate Governance: An International Review 15 (2):223-238. doi: 10.1111/j.1467-8683.2007.00556.x.

Doidge, Craig. 2004. "U.S. cross-listings and the private benefits of control: evidence from dual-class firms." Journal of financial economics 72 (3):519-553. doi: 10.1016/s0304-405x(03)00208-3.

Fama, Eugene F., and Michael C. Jensen. 1983. "Separation of Ownership and Control." Journal of Law and Economics 26 (2):301-325.

Francis, Jennifer, Allen H. Huang, Shivaram Rajgopal, and Amy Y. Zang. 2008. "CEO Reputation and Earnings Quality." Contemporary Accounting Research 25 (1):109-147. doi: 10.1506/car.25.1.4.

Francis, Jennifer, Ryan LaFond, Per M. Olsson, and Katherine Schipper. 2004. "Costs of Equity and Earnings Attributes." The Accounting Review 79 (4):967-1010. doi: 10.2308/accr.2004.79.4.967.

Francis, Jennifer, Ryan LaFond, Per Olsson, and Katherine Schipper. 2005. "The market pricing of accruals quality." Journal of Accounting and Economics 39 (2):295-327. doi: 10.1016/j.jacceco.2004.06.003.

Freeman, R. Edward. 1984. Strategic management: a stakeholder approach. Boston: Pitman.

Friedman, Milton. 1970. "The Social Responsibility of Business Is to Increase Its Profits." New York Times Magazine:32.

Ghazali, Nazli A. Mohd, and Pauline Weetman. 2006. "Perpetuating traditional influences: voluntary disclosure in Malaysia following the economic crisis." Journal of international accounting auditing \& taxation 15 (2):226-248. doi: 10.1016/j.intaccaudtax.2006.08.001.

Gujarati, Damodar N., and Dawn C. Porter. 2009. Basic econometrics. Boston: McGraw-Hill Irwin.

Gul, Ferdinand A., Marion Hutchinson, and Karen M. Y. Lai. 2013. "Gender-Diverse Boards and Properties of Analyst Earnings Forecasts." Accounting Horizons 27 (3):511-538. doi: 10.2308/acch-50486. 
Hail, Luzi, and Christian Leuz. 2009. "Cost of capital effects and changes in growth expectations around U.S. cross-listings." Journal of financial economics 93 (3):428-454. doi: http://dx.doi.org/10.1016/j.jfineco.2008.09.006.

Hair, Joseph F. 1998. Multivariate data analysis. Upper Saddle River, N.J: Prentice-Hall International.

Haji, Abdifatah Ahmed. 2013. "Corporate social responsibility disclosures over time: evidence from Malaysia." Managerial Auditing Journal 28 (7):647-676. doi: 10.1108/maj-07-2012-0729.

Haniffa, R. M., and T. E. Cooke. 2005. "The impact of culture and governance on corporate social reporting." Journal of Accounting and Public Policy 24 (5):391-430. doi: 10.1016/j.jaccpubpol.2005.06.001.

Hartley, James, and Lucy R. Betts. 2010. "Four layouts and a finding: the effects of changes in the order of the verbal labels and numerical values on Likert-type scales." International Journal of Social Research Methodology 13 (1):17-27. doi: 10.1080/13645570802648077.

Healy, P., K. Palepu, and A. Sweeney. 1995. "Do firms benefit from expanded voluntary disclosure?" Working paper., MIT Sloan School of Management, Cambridge, MA.

Ho, Poh-Ling, Greg Tower, and Grantley Taylor. 2013. "Corporate governance, ownership structure and voluntary disclosure: evidence from listed firms in Malaysia." Afro-Asian J. of Finance and Accounting 3 (4):319-340.

Inchausti, A. Giner. 1997. "The influence of company characteristics and accounting regulation on information disclosed by Spanish firms." European Accounting Review 6 (1):45-68. doi: $10.1080 / 096381897336863$

Jiang, Haiyan, and Ahsan Habib. 2009. "The impact of different types of ownership concentration on annual report voluntary disclosures in New Zealand." Accounting Research Journal 22 (3):275-304. doi: 10.1108/10309610911005590.

Jones, Thomas M. 1995. "Instrumental Stakeholder Theory: A Synthesis of Ethics and Economics." The Academy of Management Review 20 (2):404-437.

Khan, Arifur, Mohammad Badrul Muttakin, and Javed Siddiqui. 2013. "Corporate Governance and Corporate Social Responsibility Disclosures: Evidence from an Emerging Economy." Journal of Business Ethics 114 (2):207-223. doi: 10.1007/s10551-012-1336-0.

Kim, Yongtae, Myung Seok Park, and Benson Wier. 2012. "Is earnings quality associated with corporate social responsibility?" The Accounting Review 87 (3):761-796. doi: 10.2308/accr10209.

Leuz, Christian, Dhananjay Nanda, and Peter D. Wysocki. 2003. "Earnings management and investor protection: an international comparison." Journal of Financial Economics 69 (3):505-527. doi: 10.1016/s0304-405x(03)00121-1.

Lipe, Robert. 1990. "The Relation between Stock Returns and Accounting Earnings Given Alternative Information." The Accounting Review 65 (1):49-71. 
Lu, Yingjun, and Indra Abeysekera. 2014. "Stakeholders' power, corporate characteristics, and social and environmental disclosure: evidence from China." Journal of Cleaner Production 64 (Journal Article):426-436. doi: 10.1016/j.jclepro.2013.10.005.

Mangena, Musa, and Venancio Tauringana. 2007. "Disclosure, corporate governance and foreign share ownership on the Zimbabwe Stock Exchange." Journal of international financial management and accounting 18 (2):53-85. doi: 10.1111/j.1467-646X.2007.01008.x.

Muttakin, Mohammad Badrul, and Arifur Khan. 2013. "Corporate governance and corporate social responsibility disclosures: evidence from an emerging economy." Journal of Business Ethics 114 (2):207-223. doi: 10.1007/s10551-012-1336-0.

Naser, K., A. Alhussaini, D. Alkwari, and R. Nuseibeh. 2006. "Determinants of Corporate Social Disclosure in Developing Countries: The Case of Qatar." Advances in International Accounting 19 (Journal Article):1-23. doi: 10.1016/s0897-3660(06)19001-7.

Petrovits, Christine M. 2006. "Corporate-sponsored foundations and earnings management." Journal of accounting \& economics 41 (3):335-362. doi: 10.1016/j.jacceco.2005.12.001.

Pham, Duc Hieu. 2011. "Corporate social responsibility: A study on awareness of managers and consumers in Vietnam." Journal of Accounting and Taxation 3 (8):162-170.

Post, Corinne, Noushi Rahman, and Emily Rubow. 2011. "Green Governance: Boards of Directors' Composition and Environmental Corporate Social Responsibility." Business \& Society 50 (1):189-223. doi: 10.1177/0007650310394542.

Prior, Diego, Jordi Surroca, and Josep A. Tribó. 2008. "Are socially responsible managers really ethical?: exploring the relationship between earnings management and corporate social responsibility." Corporate governance 16 (3):160-177. doi: 10.1111/j.14678683.2008.00678.x.

Purushothaman, Maya, Greg Tower, Phil Hancock, and Ross Taplin. 2000. "Determinants of corporate social reporting practices of listed Singapore companies." Pacific Accounting Review 12 (2):101.

Said, Roshima, Yuserrie Hj Zainuddin, and Hasnah Haron. 2009. "The relationship between corporate social responsibility disclosure and corporate governance characteristics in Malaysian public listed companies." Social Responsibility Journal 5 (2):212-226. doi: doi:10.1108/17471110910964496.

Scholtens, Bert, and Feng Ching Kang. 2013. "Corporate Social Responsibility and Earnings Management: Evidence from Asian Economies." Corporate Social Responsibility and Environmental Management 20 (2):95-112. doi: 10.1002/csr.1286.

Siciliano, Julie I. 1996. "The Relationship of Board Member Diversity to Organizational Performance." Journal of Business Ethics 15 (12):1313-1320. doi: 10.1007/bf00411816. 
Srinidhi, B. I. N. , F. A. Gul, and J. Tsui. 2011. "Female directors and earnings quality." Contemporary Accounting Research 28 (5):1610-1644. doi: 10.1111/j.19113846.2011.01071.x.

Staiger, Douglas, and James H. Stock. 1997. "Instrumental Variables Regression with Weak Instruments." Econometrica 65 (3):557-586.

Stock, James H, and Motohiro Yogo. 2005. Testing for weak instruments in linear IV regression. Chapter 5 in Identification and Inference in Econometric Models: Essays in Honor of Thomas J. Rothenberg, edited by DWK Andrews and JH Stock. Cambridge: Cambridge University Press.

Uwuigbe, Uwalomwa, and Ben-Caleb Egbide. 2012. "Corporate Social Responsibility Disclosures in Nigeria: A Study of Listed Financial and Non-Financial Firms." Journal of Management and Sustainability 2 (1):160-169.

Vu, Greg Tower, and Glennda Scully. 2011a. "Corporate communication for Vietnamese listed firms." Asian Review of Accounting 19 (2):125-146. doi: 10.1108/13217341111181069.

Vu, K.A., Greg Tower, and Glennda Scully. 2011b. "Corporate communication for Vietnamese listed firms." Asian Review of Accounting 19 (2):125-146. doi: 10.1108/13217341111181069.

Vu, K.B.A.H. 2012. "Determinants of Voluntary Disclosure for Vietnamese Listed Firms." Doctoral Thesis Doctoral Thesis, School of Accounting, Curtin University.

Wang, Liu, and Kenneth Yung. 2011. "Do State Enterprises Manage Earnings More than Privately Owned Firms? The Case of China." Journal of Business Finance \& Accounting 38 (7 8):794-812. doi: 10.1111/j.1468-5957.2011.02254.x.

Weetman, Pauline, and Nazli A. Mohd Ghazali. 2006. "Perpetuating traditional influences: voluntary disclosure in Malaysia following the economic crisis." Journal of international accounting auditing \& taxation 15 (2):226-248. doi: 10.1016/j.intaccaudtax.2006.08.001.

White, Halbert. 1980. "A Heteroskedasticity-Consistent Covariance Matrix Estimator and a Direct Test for Heteroskedasticity." Econometrica 48 (4):817-838.

Williams, Robert J. 2003. "Women on Corporate Boards of Directors and Their Influence on Corporate Philanthropy." Journal of Business Ethics 42 (1):1-10. doi: 10.1023/a:1021626024014.

Wysocki, P. 2006. "Assessing earnings and accrual quality: U.S. and international evidence." Working Paper, Massachusetts Institute of Technology.

Xiao, Huafang, and Jianguo Yuan. 2007. "Ownership structure, board composition and corporate voluntary disclosure: Evidence from listed companies in China." Managerial Auditing Journal 22 (6):604-619. doi: 10.1108/02686900710759406.

Yip, Erica, Chris van Staden, and Steven Cahan. 2011. "Corporate Social Responsibility Reporting and Earnings Management: The Role of Political Costs." Australasian Accounting Business \& Finance Journal 5 (3):17-34. 
Zhang, Jason Q., Hong Zhu, and Hung-bin Ding. 2013. "Board Composition and Corporate Social Responsibility: An Empirical Investigation in the Post Sarbanes-Oxley Era." Journal of Business Ethics 114 (3):381-392. doi: 10.1007/s10551-012-1352-0.

Table 1. List of 45 items with the mean importance weighted by four stakeholder-specific groups for disclosure items and types, in their order of relative importance of items.

Panel A

List of 15 labor items and the mean importance weighted by employees for disclosure items and disclosure types.

\begin{tabular}{|c|c|c|c|c|c|c|}
\hline \multirow{2}{*}{$\begin{array}{l}\text { Labor items } \\
\text { (LA) }\end{array}$} & \multirow{2}{*}{$\begin{array}{c}\text { Mean weight } \\
\text { of items } \\
\text { disclosed }\end{array}$} & \multicolumn{4}{|c|}{ Mean weight of each type of disclosure } & \multirow{2}{*}{$\begin{array}{l}\text { Total number of } \\
\text { firms disclosing } \\
\text { item }\end{array}$} \\
\hline & & Narrative & Monetary & Numerical & $\begin{array}{l}\text { Both monetary } \\
\text { and numerical }\end{array}$ & \\
\hline LA11 & 7.47 & 6.53 & 6.75 & 6.92 & 7.51 & 86 \\
\hline LA7 & 7.38 & 6.28 & 6.00 & 7.17 & 7.06 & 14 \\
\hline LA8 & 7.29 & 6.49 & 6.31 & 7.02 & 6.97 & 52 \\
\hline LA4 & 7.28 & 6.22 & 5.99 & 7.19 & 6.92 & 26 \\
\hline LA5 & 7.28 & 6.34 & 5.99 & 7.09 & 6.84 & 4 \\
\hline LA9 & 7.27 & 6.54 & 6.37 & 7.06 & 6.88 & 28 \\
\hline LA3 & 7.18 & 6.15 & 7.00 & 7.19 & 7.68 & 7 \\
\hline LA2 & 7.15 & 6.03 & 5.85 & 6.92 & 6.69 & 38 \\
\hline LA12 & 7.11 & 6.65 & 6.10 & 7.10 & 7.12 & 57 \\
\hline LA10 & 7.05 & 6.20 & 6.02 & 6.94 & 6.90 & 89 \\
\hline LA1 & 6.97 & 5.77 & 5.85 & 7.04 & 7.27 & 124 \\
\hline LA14 & 6.78 & 5.84 & 6.35 & 6.74 & 7.16 & 54 \\
\hline LA 15 & 6.7 & 5.73 & 5.69 & 6.88 & 6.90 & 8 \\
\hline LA6 & 6.47 & 5.94 & 5.60 & 6.69 & 6.34 & 15 \\
\hline LA13 & 6.44 & 5.97 & 5.27 & 6.53 & 6.26 & 133 \\
\hline
\end{tabular}

Panel B

List of 11 human rights items and the mean importance weighted by lawyers and regulators for disclosure items and disclosure types.

\begin{tabular}{lcccccc}
\hline \multirow{2}{*}{$\begin{array}{l}\text { Human rights } \\
\text { items (HR) }\end{array}$} & $\begin{array}{c}\text { Mean weight } \\
\text { of items } \\
\text { disclosed }\end{array}$ & \multicolumn{4}{c}{ Nean weight of each type of disclosure } & $\begin{array}{c}\text { Total number of } \\
\text { firms disclosing } \\
\text { item }\end{array}$ \\
\hline HR7 & 8.19 & 5.27 & Monetary & Numerical & $\begin{array}{c}\text { Both monetary } \\
\text { and numerical }\end{array}$ & (itive \\
HR11 & 7.98 & 5.19 & 6.00 & 7.90 & 6.64 & 2 \\
HR4 & 7.9 & 5.28 & 5.25 & 7.64 & 6.76 & 4 \\
HR6 & 7.89 & 5.43 & 6.07 & 7.89 & 7.21 & 9 \\
HR5 & 7.28 & 4.91 & 5.23 & 6.99 & 6.32 & 5 \\
HK9 & 7.19 & 5.26 & 5.62 & 6.79 & 6.61 & 3 \\
HR3 & 7.18 & 4.62 & 5.64 & 7.03 & 6.82 & 10 \\
HR8 & 6.93 & 5.53 & 5.83 & 6.96 & 6.53 & 1 \\
HR10 & 6.71 & 4.87 & 5.17 & 6.45 & 6.41 & 5 \\
HR1 & 6.69 & 4.71 & 6.01 & 7.05 & 7.68 & 6 \\
HR2 & 6.38 & 4.55 & 5.30 & 6.75 & 6.97 & 1 \\
\hline
\end{tabular}


Panel C

List of 10 items of societal aspects and the mean importance weighted by local communities for disclosure items and disclosure types.

\begin{tabular}{|c|c|c|c|c|c|c|}
\hline \multirow[b]{2}{*}{$\begin{array}{l}\text { Societal items } \\
\text { (SO) }\end{array}$} & \multicolumn{5}{|c|}{ Mean weight of each type of disclosure } & \multirow{2}{*}{$\begin{array}{l}\text { Total number of } \\
\text { firms disclosing } \\
\text { item }\end{array}$} \\
\hline & $\begin{array}{l}\text { Mean weight } \\
\text { of items } \\
\text { disclosed }\end{array}$ & Narrative & Monetary & Numerical & $\begin{array}{l}\text { Both } \\
\text { monetary } \\
\text { and } \\
\text { numerical }\end{array}$ & \\
\hline $\mathrm{SO} 2$ & 7.92 & 4.91 & 6.35 & 6.50 & 7.58 & 1 \\
\hline SO8 & 7.81 & 5.49 & 6.98 & 6.99 & 7.90 & 11 \\
\hline SO1 & 7.67 & 4.61 & 6.53 & 6.04 & 7.97 & 60 \\
\hline SO10 & 7.52 & 5.06 & 5.87 & 6.22 & 7.43 & 25 \\
\hline $\mathrm{SO} 4$ & 7.41 & 5.11 & 6.10 & 6.55 & 7.55 & 3 \\
\hline SO7 & 7.35 & 5.45 & 6.12 & 6.36 & 7.38 & 23 \\
\hline SO9 & 7.26 & 4.79 & 5.58 & 6.09 & 7.32 & 7 \\
\hline $\mathrm{SO} 3$ & 7.24 & 5.06 & 5.74 & 6.57 & 7.34 & 0 \\
\hline SO6 & 6.94 & 4.88 & 6.21 & 6.09 & 7.33 & 1 \\
\hline $\mathrm{SO} 5$ & 6.22 & 4.88 & 5.46 & 5.73 & 6.44 & 0 \\
\hline
\end{tabular}

Panel D

List of 9 product items and the mean importance weighted by customers for disclosure items and disclosure types

\begin{tabular}{lccccccc}
\hline \multirow{2}{*}{$\begin{array}{l}\text { Product items } \\
\text { (PR) }\end{array}$} & $\begin{array}{l}\text { Mean weight } \\
\text { of items } \\
\text { disclosed }\end{array}$ & Narrative & Monetary & Numerical & $\begin{array}{l}\text { Both monetary } \\
\text { and numerical }\end{array}$ & $\begin{array}{l}\text { Number of } \\
\text { firms disclosing } \\
\text { item }\end{array}$ \\
\hline PR1 & 8.08 & 5.22 & 6.14 & 6.58 & 7.68 & 83 \\
PR5 & 8.07 & 6.30 & 6.17 & 7.08 & 7.76 & 42 \\
PR9 & 7.8 & 5.61 & 6.56 & 6.70 & 8.09 & 7 \\
PR8 & 7.77 & 5.97 & 6.02 & 6.64 & 7.11 & 0 \\
PR3 & 7.71 & 5.88 & 5.43 & 6.09 & 6.74 & 133 \\
PR7 & 7.64 & 5.56 & 5.62 & 6.49 & 7.35 & 16 \\
PR6 & 6.98 & 6.05 & 5.68 & 5.60 & 5.89 & 133 \\
PR2 & 6.94 & 5.57 & 5.63 & 6.21 & 6.53 & 6 \\
PR2 & 6.62 & 5.59 & 5.28 & 5.57 & 6.13 & 0 \\
\hline
\end{tabular}

Table 2. Descriptive statistics

\begin{tabular}{lcccc}
\hline \multicolumn{1}{c}{ Variables } & Mean & SD & Min & Max \\
\hline $\begin{array}{l}\text { Dependent variable } \\
\text { CSD_INDEX }\end{array}$ & 0.10 & 0.05 & 0.03 & 0.23 \\
\hline Four sub-categories of CSD-Additional analysis & & & & \\
LAD_INDEX & 0.17 & 0.08 & 0.03 & 0.41 \\
SOD_INDEX & 0.04 & 0.05 & 0 & 0.23 \\
PRD_INDEX & 0.16 & 0.05 & 0.1 & 0.3 \\
HRD_INDEX & 0.01 & 0.04 & 0 & 0.25 \\
\hline Independent variable & & & & \\
EQ & 67.00 & 24.74 & 1.00 & 112.00 \\
\hline
\end{tabular}


Four earnings attributes to construct the standardized aggregate earnings quality score

\begin{tabular}{lcccc} 
AQ & 0.06 & 0.06 & 0.00 & 0.40 \\
PERSIS & -0.44 & 0.86 & -2.80 & 4.78 \\
PREDICT & 0.07 & 0.07 & 0.01 & 0.40 \\
SMOOTH & 0.48 & 0.45 & 0.03 & 2.65 \\
\hline Control variables & & & & \\
STATE & 0.27 & 0.21 & 0.00 & 0.79 \\
FOREIGN & 0.12 & 0.14 & 0.00 & 0.49 \\
AUDIT & 0.16 & 0.37 & 0 & 1 \\
ROA & 0.08 & 0.08 & -0.17 & 0.39 \\
STOCK_EX & 0.68 & 0.47 & 0 & 1 \\
FEMALE & 0.14 & 0.15 & 0.00 & 0.60 \\
\hline
\end{tabular}

This table shows summary statistics for variables used in this paper. The final sample consists of 133 firms listed on Ho Chi Minh and Hanoi stock exchanges for the 2010 sample.

CSD_INDEX $=$ the stakeholder-driven, three-dimensional CSD index;

LAD_INDEX $=$ the stakeholder-driven, three-dimensional labor aspect disclosure index;

SOD_INDEX $=$ the stakeholder-driven, three-dimensional society aspect disclosure index;

PRD_INDEX $=$ the stakeholder-driven, three-dimensional product responsibility aspect disclosure index;

HRD_INDEX = the stakeholder-driven, three-dimensional human rights aspect disclosure index;

$\mathrm{EQ}=$ the standardized aggregate earnings quality score, calculated as the average rank across the four individual measures (accruals quality, earnings persistence, earnings predictability, and earnings smoothness);

$A Q$, PESIS, PREDICT, SMOOTH = the values of accruals quality, earnings persistence, earnings predictability, and earnings smoothness, respectively;

STATE $=$ the percentage of shareholding owned by the state;

FOREIGN $=$ the percentage of shareholding owned by foreign investors;

AUDIT $=1$ if firm's auditor is a Big 4 and 0 if otherwise;

ROA $=$ net profit over the total assets;

STOCK_EX $=1$ if the firm is listed on HOSE and 0 for firms listed on HNX;

FEMALE $=$ the percentage of female members in the board of directors.

Table 3.

The relationship between earnings quality and stakeholder-relevant CSD and the moderating effect of the ownership structure on this relationship.

\begin{tabular}{|c|c|c|c|c|}
\hline & \multicolumn{2}{|c|}{ CSD_INDEX (1) } & \multicolumn{2}{|c|}{ CSD_INDEX (2) } \\
\hline & Coeff. & $\mathrm{p}$-value & Coeff. & $\mathrm{p}$-value \\
\hline$E Q$ & $0.0003^{*}$ & 0.079 & $0.0008 * * *$ & 0.007 \\
\hline EQ $\times$ STATE & & & $-0.0015 * *$ & 0.034 \\
\hline$E Q \times F O R E I G N$ & & & -0.0012 & 0.295 \\
\hline STATE & -0.0056 & 0.763 & $0.0925 *$ & 0.063 \\
\hline FOREIGN & -0.0284 & 0.357 & 0.0379 & 0.604 \\
\hline AUDIT & $0.0334 * * *$ & 0.002 & $0.0343 * * *$ & 0.001 \\
\hline$R O A$ & $0.1105^{* *}$ & 0.046 & $0.1055^{*}$ & 0.054 \\
\hline STOCK_EX & $0.0306^{* * *}$ & 0.000 & $0.0326 * * *$ & 0.000 \\
\hline FEMALE & $0.0643 * * *$ & 0.010 & $0.0633 * * *$ & 0.010 \\
\hline Constant & 0.0429 & 0.007 & 0.0080 & 0.727 \\
\hline $\mathrm{R}^{2}$ & \multicolumn{2}{|c|}{0.2507} & \multicolumn{2}{|c|}{0.2796} \\
\hline Adjusted $\mathrm{R}^{2}$ & \multicolumn{2}{|c|}{0.2088} & \multicolumn{2}{|c|}{0.2268} \\
\hline F statistic & \multicolumn{2}{|c|}{$5.98 * * *$} & \multicolumn{2}{|c|}{$5.3 * * *$} \\
\hline$p$-value & \multicolumn{2}{|c|}{0.000} & \multicolumn{2}{|c|}{0.000} \\
\hline
\end{tabular}


The sample consists of 133 firms listed on Ho Chi Minh and Hanoi stock exchanges, each with a continuous listing history over the entire period from 2005 to 2011 for the 2010 sample. The p-values are calculated using standard errors corrected for heteroscedasticity. *,**, and $* * *$ denote significance levels at $10 \%, 5 \%$, and $1 \%$, respectively.

Table 4.

Stakeholder-relevant CSD and earnings quality: Excluding the accruals quality measure in the standardized aggregate earnings quality score.

\begin{tabular}{|c|c|c|c|c|}
\hline & \multicolumn{2}{|c|}{ CSD_INDEX (1) } & \multicolumn{2}{|c|}{ CSD INDEX (2) } \\
\hline & Coeff. & p-value & Coeff. & $\mathrm{p}$-value \\
\hline EQ_3ATTRI & $0.0003 * *$ & 0.037 & $0.0007 * * *$ & 0.009 \\
\hline EQ_3ATTRI x STATE & & & $-0.0012 *$ & 0.077 \\
\hline EQ_3ATTRI x FOREIGN & & & -0.0008 & 0.419 \\
\hline STATE & -0.0058 & 0.754 & 0.0717 & 0.130 \\
\hline FOREIGN & -0.0263 & 0.390 & 0.0196 & 0.770 \\
\hline AUDIT & $0.0326 * * *$ & 0.002 & $0.0338 * * *$ & 0.001 \\
\hline$R O A$ & $0.1095^{* *}$ & 0.043 & $0.1042 *$ & 0.053 \\
\hline STOCK_EX & $0.0302 * * *$ & 0.000 & $0.0317 * * *$ & 0.000 \\
\hline FEMALE & $0.0630 * * *$ & 0.010 & $0.0627 * *$ & 0.011 \\
\hline Constant & $0.0422 * * *$ & 0.004 & 0.0161 & 0.434 \\
\hline $\mathrm{R}^{2}$ & \multicolumn{2}{|c|}{0.2583} & \multicolumn{2}{|c|}{0.2789} \\
\hline Adjusted $\mathrm{R}^{2}$ & \multicolumn{2}{|c|}{0.2168} & \multicolumn{2}{|c|}{0.2261} \\
\hline F statistic & \multicolumn{2}{|c|}{$6.22 * * *$} & \multicolumn{2}{|c|}{$5.29 * * *$} \\
\hline p-value & \multicolumn{2}{|c|}{0.000} & \multicolumn{2}{|c|}{0.000} \\
\hline Mean VIF & \multicolumn{2}{|c|}{1.28} & \multicolumn{2}{|c|}{4.59} \\
\hline
\end{tabular}

EQ_3ATTRI is the firm-specific standardized aggregate earnings quality score proxy, the average rank across three measures (PERSIS, PREDICT, and SMOOTH). The sample consists of 133 firms listed on Ho Chi Minh and Hanoi stock exchanges, each with a continuous listing history over the entire period from 2005 to 2011 for the 2010 sample. The $\mathrm{p}$-values are calculated using standard errors corrected for heteroscedasticity. $*, * *$, and $* * *$ denote significance levels at $10 \%, 5 \%$, and $1 \%$, respectively.

Table 5.

Earnings quality and labor and society aspects of stakeholder-relevant disclosure quality

\begin{tabular}{lccccc}
\hline & \multicolumn{2}{c}{ LAD\&SOD_INDEX $(1)$} & & \multicolumn{2}{c}{ LAD\&SOD_INDEX (2) } \\
\cline { 2 - 3 } \cline { 5 - 6 } & Coeff. & p-value & & Coeff. & p-value \\
\hline EQ & $0.0004^{*}$ & 0.061 & & $0.0012^{* * *}$ & 0.005 \\
EQ x STATE & & & & $-0.0019^{* *}$ & 0.045 \\
EQ x FOREIGN & & & & -0.0021 & 0.165 \\
STATE & 0.0010 & 0.969 & & $0.1276^{*}$ & 0.061 \\
FOREIGN & -0.0132 & 0.754 & & 0.1094 & 0.276 \\
AUDIT & $0.0334^{* *}$ & 0.020 & & $0.0341^{* *}$ & 0.018 \\
ROA & $0.1525^{* *}$ & 0.044 & & $0.1450^{*}$ & 0.053 \\
STOCKEXCHANGE & $0.0347^{* * *}$ & 0.003 & & $0.0381^{* * *}$ & 0.001 \\
FEMALE & $0.0909^{* * *}$ & 0.008 & & $0.0909^{* * *}$ & 0.007 \\
Constant & $0.0402^{*}$ & 0.065 & & -0.0104 & 0.741 \\
$\mathrm{R}^{2}$ & & 0.2138 & & & \multicolumn{2}{c}{0.2445}
\end{tabular}


Adjusted $\mathrm{R}^{2}$

F statistic

p-value

LAD\&SOD_INDEX represents society and labor aspects of the disclosure index (the dependent variable).

\section{Table 6.}

\section{First-stage regression summary statistics}

Panel A: Earnings quality and CSD

\begin{tabular}{llllll}
\hline Variable & $\mathrm{R}^{2}$ & Adjusted $\mathrm{R}^{2}$ & Partial $\mathrm{R}^{2}$ & $\mathrm{~F}$ & Prob $>\mathrm{F}$ \\
\hline EQ & 0.308 & 0.263 & 0.148 & $\mathbf{1 0 . 7 4}$ & 0.0001 \\
\hline
\end{tabular}

Critical Values \# of endogenous regressors: 1

Ho: Instruments are weak \# of excluded instruments: 2

\begin{tabular}{lllll}
\hline & $10 \%$ & $15 \%$ & $20 \%$ & $25 \%$ \\
LIML Size of nominal 5\% Wald test & $\mathbf{8 . 6 8}$ & $\mathbf{5 . 3 3}$ & $\mathbf{4 . 4 2}$ & $\mathbf{3 . 9 2}$ \\
\hline
\end{tabular}

Panel B: The moderating effect of ownership structure on the relationship between earnings quality and CSD

\begin{tabular}{llllll}
\hline Variable & $\mathrm{R}^{2}$ & Adjusted $\mathrm{R}^{2}$ & Partial $^{2}$ & $\mathrm{~F}$ & Prob $>\mathrm{F}$ \\
\hline EQ & 0.797 & 0.781 & 0.092 & $\mathbf{6 . 1 7}$ & 0.0028 \\
\hline
\end{tabular}

Critical Values \# of endogenous regressors: 1

Ho: Instruments are weak \# of excluded instruments: 2

\begin{tabular}{lllll}
\hline & $10 \%$ & $15 \%$ & $20 \%$ & $25 \%$ \\
LIML Size of nominal 5\% Wald test & 8.68 & 5.33 & 4.42 & 3.92 \\
\hline
\end{tabular}

Table 7.

Earnings quality and stakeholder-relevant CSD using limited-information maximum likelihood (LIML) regression method

\begin{tabular}{lllllllll}
\hline & EQ & STATE & FOREIGN & AUDIT & ROA & STOCKEXCHANGE & FEMALE & Constant \\
\hline Coeff. & 0.0008 & -0.0125 & -0.0381 & 0.0356 & 0.1665 & 0.0350 & 0.0719 & 0.0049 \\
\hline p-value & 0.066 & 0.521 & 0.231 & 0.001 & 0.019 & 0.000 & 0.004 & 0.886 \\
\hline Significance * & & & $* * *$ & $* *$ & $* * *$ & $* * *$ &
\end{tabular}

$\mathrm{R}^{2}=0.196$, Wald statistic $=41.71, \mathrm{p}$-value $=0.000, \mathrm{~N}=133$.

$*, * *$, and $* * *$ denote significance levels at $10 \%, 5 \%$, and $1 \%$, respectively. 